\title{
Letters
}

Website: www.bmj.com

Email: letters@bmj.com

\section{Smear tests were not on trial but should have been}

EDITOR-In February three women were declared victims of medical negligence because their smear abnormalities were missed at the Kent and Canterbury Hospital. $^{1}$

This raises some serious questions. Did the judge understand how reliably the smear test performs under day to day conditionsthat for every 90000 slides reviewed several hundred will be reallocated a new category? Did he know that borderline cases and inadequate samples are not included in quality assurance tests in the United Kingdom because they cannot be agreed on? The rate of interobserver agreement even between experts is rarely better than $80 \%$ and is lower for milder abnormalities. Consent forms and disclaimers in the United States say that $5-15 \%$ of abnormal smears may be deemed normal. The guidelines of the College of American Pathologists for reviewing cervical smears in the context of litigation or potential litigation state that a false negative smear is not necessarily evidence of practice below standard care, that borderline smears represent a poorly defined diagnosis with poor interobserver and intraobserver reproducibility, and that smears should be reviewed without knowledge of clinical outcome and in an environment that simulates the normal screening practice as closely as possible. ${ }^{2}$

Was this last condition met in this case? If not, how can the Bolam test have been applied? Furthermore, the three women argued that if their smear abnormalities had been picked up in time cancer would have been prevented. But this cannot be assumed: some women die of cervical cancer even when everything has been done properly in detection and treatment.

In this case the screening programme itself seems to have been on trial and robustly defended. In his summing up, the judge urged women not to be afraid of having a smear test, adding that the national programme had been a great success in reducing the number of deaths from cervical cancer, which was declining at the rate of $7 \%$ each year. He did not say that only part of this reduction is due to screening: the rest is because cervical cancer is spontaneously declining in the United Kingdom. General practitioners have been urged to tell women that the smear test is not foolproof and that they should report abnormal bleeding to their doctor." After 30 years of screening, why has this message not got through and why was it not repeated here? A landmark opportunity for promoting honesty about the limitations of screening has been missed. The consequences for my patients, especially young ones, will be increased overdiagnosis and unnecessary treatments.

\section{Mary Anderson General practitioner}

Heaton Moor Medical Centre, Stockport SK4 4NX

Competing interests: Promoting greater honesty about the limitations of the smear test may conflict with my financial interest (target payments in general practice).

1 Dyer C. Three women win in cancer screening case. BMJ 1999;318:484. (20 February.)

2 College of American Pathologists. Guidelines for review of Pap smears in the context of litigation or potential litigation. Adopted 2/98. (www.cap.org/html/advocacy/ cappoints/papdochtml [15 February 1998]).

3 Patnick J. GPs urged to tell women smear test no foolproof. Pulse 1998 Sep 5:22.

\section{Postcoital testing}

\section{Criterion for positive test was not given}

EDITOR-In their report on postcoital testing Oei et al applied inappropriate trial methods to the use of a diagnostic rather than a therapeutic procedure. ${ }^{1}$ Their interpretation was consequently misleading and further invalidated by biased selectivity. A diagnostic procedure cannot alter outcome, except by influencing the choice of treatment specific to a diagnosis. Numerous treatments were applied non-specifically and inconsistently, invalidating study outcome. Intrauterine insemination was incorrectly described as specific for negative postcoital findings but is used equally, like in vitro fertilisation, in couples who tested positive, although success rates differ.

The only significant finding was that the sum frequency of more than five different treatments used was slightly greater in tested couples than in those not tested (54\% versus $41 \%$ ). Invasive investigations (hysterosalpingography, laparoscopy) were, however, apparently used less frequently in the tested group. Pregnancy rates were not significantly different between couples with negative and positive tests, but no account was taken of possible effects of the treatment, or (in that part of the analysis) of the likelihood that couples who conceived too soon to be tested would have had a positive test result.

Oei et al did not mention their criterion for a positive test although there is 10 -fold variation in use between centres, based on arbitrary choice. Several reports use the properly derived criterion of one progressively motile spermatozoon per high power microscope field, and properly controlled outcome (pregnancy rate) studies, and they describe the distinguishing power of postcoital testing, but none were mentioned by Oei et al. These include studies of natural conception rates without treatment in otherwise unexplained infertility. ${ }^{2-4}$ Furthermore, the predictive power of postcoital testing has been shown to override that of semen analysis, ${ }^{34}$ which is consistently a weak predictor of fertility except when sperm numbers are severely depleted. In vitro testing of interaction between sperm and mucus has also been shown repeatedly to be prognostic for natural conception and to correlate with in vitro fertilising ability of spermatozoa for assisted conception. ${ }^{2}{ }^{3}$

Duration of infertility is an important prognostic factor affecting the chance of natural conception, particularly in unexplained infertility. ${ }^{5}$ Prolonged duration reduces the prognostic optimism after a positive postcoital test (unpublished data). Therefore, the test is of predictive value for natural conception mainly in couples with less than three years' duration of otherwise unexplained infertility, although it remains predictive for fertilisation in vitro and therefore for choice of assisted conception method, even after prolonged infertility.

M G R Hull Professor of reproductive medicine and surgery

University of Bristol, Division of Obstetrics and Gynaecology, St Michael's Hospital, Bristol BS2 8EG

J L H Evers Professor of obstetrics and gynaecology Academisch Ziekenhuis Maastricht, NL-6202 AZ Maastricht, Netherlands 1 Oei SG, Helmerhorst FM, Bloemenkamp KWM, Hollants
FAM, Meerpoel DEB, Keirse JNC. Effectiveness of the
postcoital test: randomised controlled trial. BMJ
1998;317:502-5. (22 August.)
2 Hull MGR. Managed care of infertility. Curr Opin Obstet
Gynaecol 1996;8:305-13.
3 Glazener CMA, Kelly NJ, Weir MJA, David SE, Comes JS,
Hull MGR. The diagnosis of male infertility-prospective
time-specific study of conception rates related to seminal
analysis and post-coital sperm-mucus penetration and
survival in otherwise unexplained infertility. Hum Reprod
1987;8:665-71.
4 Snick HKA, Snick TS, Evers JLH, Collins JA. The
spontaneous pregnancy prognosis in untreated subfertile
couples: the Walcheren primary care study. Hum Reprod
1997;12:1582-8.
5 Hull MGR, Glazener CMA, Kelly NJ, Conway DI, Foster
PA, Hinton RA, etal. Population study of causes, treatment,
and outcome of infertility. BMJ 1985;291:1693-7.

\section{Male partner should be assessed}

EDITOR-In their article on the effectiveness of the postcoital test ${ }^{1}$ Oei et al failed to mention the work of Kremer et al, which showed that the most common cause of unexplained 
poor results of postcoital testing is autoantibodies to spermatozoa in the male partner, which prevent sperm penetration of cervical mucus. ${ }^{2}$ This affects the function of the spermatozoa not only in the partner's cervical mucus but also in any woman's mucus, as can be shown by crossed hostility testing."

Failure to test for such antibodies-for example, by routine mixed antiglobulin reaction testing ${ }^{4}$ of the male partner's spermatozoa-will leave observers just as confused about "cervical hostility" as they were over 20 years ago. To do postcoital tests without understanding the implications of the result and then apply artificial insemination (a treatment that does not work well for this condition) is unlikely to achieve significance. Successful treatment is available for autoimmunity to spermatozoa in men, as shown by a double blind prospective controlled trial. ${ }^{5}$ The study by Oei et al failed to assess the male partner adequately. This places undue reliance on assisted reproductive techniques rather than critical evaluation of what is wrong with the couple concerned-all very well for those who can afford it, but not very helpful for those who cannot.

William Forbes Hendry Consultant urologist St Bartholomew's Hospital, London EC1A 7BE 106104.1742@compuserve.com

1 Oie SG, Helmerhorst FM, Bloemenkamp KWM, Hollant FAM, Meerpoel DEM, Keirse MJNC. Effectiveness of the postcoital test: randomised controlled trial. BMJ 1998;317 502-5. (22 August.)

2 Kremer J, Jager S, Van Slochteren-Draaisma T. The "unexplained," poor post coital test. Int J Fertil 1978;23:277-81.

3 Morgan H, Stedronska J, Hendry WF, Chamberlain GF, Dewhurst W. Sperm/cervical-mucus crossed hostility testing and antisperm antibodies in the husband. Lance 1977;1:1228-30.

4 Hendry WF. Detection and treatment of antispermatozoal antibodies in men. Reprod Fertil Dev 1989;1:205-22.

5 Hendry WF, Hughes L, Scammell G, Pryor JP Hargreave TB. Comparison of prednisolone and placebo in subfertile men with antibodies to spermatozoa. Lancet 1990;335: 85-8.

\section{Postcoital test should be performed as routine infertility test}

EDITOR-Oei et al concluded that the use of the postcoital test is no longer defendable as no effective fertility treatment exists; the test's diagnostic and prognostic perform- ance is poor; it creates a need for additional diagnostic tests and treatments; and it does not lead to improved pregnancy rates. ${ }^{1}$ The guidelines of evidence based medicine were not adhered to. Oei et al did not include all randomised trials or discuss the large clinical heterogeneity among these.

We retrieved five randomised trials investigating the efficacy of intrauterine insemination in case of an abnormal postcoital test. The table shows that intrauterine insemination is effective (common odds ratio $2.6 ; 95 \%$ confidence interval 1.5 to 4.4). Two trials, however, used different materials and methods. ${ }^{2 .}$ Exclusion of these results in an even higher common odds ratio of 4.0 (2.1 to 7.4). The table shows that the number of couples participating in Oe et al's trial is too small to conclude that intrauterine insemination is ineffective. Therefore, to state that there is no proved effective treatment after negative test results is not only incorrect but also leads to the impression that Oei et al were prejudiced against postcoital testing. The claim of poor prognostic performance therefore also breaks down, because the comparable percentages of $38 \%$ versus $34 \%$ are given under the assumption that intrauterine insemination is ineffective.

Oei et al concluded that the use of a postcoital test results in more tests. The control group, however, did not have a postcoital test as part of the study design. Distracting the postcoital test in the intervention group results in about the same number of investigations in both groups. Not performing a postcoital test resulted in a significantly higher number of invasive tests: hysterosalpingography and laparoscopy were performed 146 times in the intervention group versus 161 times in the control group $\left(\chi^{2}=5.1 ; \mathrm{P}<0.05\right)$.

We were surprised by the conclusion that performing a postcoital test results in more treatments. Why should a negative or positive postcoital test result in more in vitro fertilisation treatments or ovulation inductions? We would like Oei et al to present the results of the postcoital tests of the couples that finally received these treatments and the pregnancy rates differentiated for a negative or positive postcoital test. Otherwise, the postcoital test is one of the most important tests in predicting the probability of spontaneous conception that may lead to postponing of sometimes harmful treatment modalities. ${ }^{4}$ We strongly believe that the postcoital test should be performed as a routine infertility test.

B J Cohlen Registrar in obstetrics and gynaecology E R te Velde Professor

Department of Reproductive Medicine, Division of Obstetrics and Gynaecology, University Hospital Utrecht, NL-3584 CX Utrecht, Netherlands

J D F Habbema Professor

Department of Public Health, Erasmus University Rotterdam, NL-3000 CA Rotterdam, Netherlands

1 Oei SG, Helmerhorst FM, Bloemenkamp KWM, Hollant FAM, Meerpoel DEM, Keirse MJNC. Effectiveness of the postcoital test: randomised controlled trial. $B M J$ 1998;317:502-5. (22 August)

2 Glazener CMA, Coulson C, Lambert PA, Watt EM, Hinton RA, Kelly NJ, et al. The value of artificial insemination with husband's semen in infertility due to failure of poswith husbands seenen in infertility due to failure of postcoital Br J Obstet Gynaecol 1987;94:774-8.

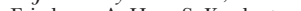

ntser J, Stewart E, Schiff I. A for insemination for cervic factor and male factor: a preliminary report. Int J Fertil 1989;34:199-203.

4 Snick HKA, Snick TS, Evers JLH, Collins JA. The spontaneous pregnancy prognosis in untreated subfertile couples: the Walcheren primary care study. Hum Reprod 1997;12:1582-8.

\section{Authors' reply}

Editor-Hull and Evers' assertion that diagnostic procedures by themselves cannot alter outcome in infertility is contradicted by mortality associated with procedures such as laparoscopy and hysterosalpingography. We agree, however, that intrauterine insemination is not a specific treatment if postcoital findings are negative, as there is no specific treatment in such circumstances. A specific diagnosis cannot be made either; Hull and Evers believe that the same test results should be interpreted differently according to duration of infertility. The inverse relationship between the prognostic optimism of a normal test and the duration of infertility may suggest that the test performs best in people without infertility. In those with infertility, it performs poorly as both

Numbers of participants having intrauterine insemination compared with timed intercourse for a negative postcoital test (all trials are statistically homogeneous $\left(\chi^{2}\right.$ 9.22))

\begin{tabular}{|c|c|c|c|c|c|c|}
\hline & \multicolumn{2}{|c|}{ Intrauterine insemination } & \multicolumn{2}{|l|}{ Coitus } & \multirow[b]{2}{*}{$\begin{array}{l}\text { Odds } \\
\text { ratio }\end{array}$} & \multirow[b]{2}{*}{$95 \% \mathrm{Cl}$} \\
\hline & Pregnancies $(n=51)$ & $\begin{array}{c}\text { Cycles } \\
(\mathrm{n}=541)\end{array}$ & Pregnancies $(n=16)$ & Cycles & & \\
\hline \multicolumn{7}{|l|}{ Reference } \\
\hline Friedman et al $\left.\right|^{3}$ & 7 & $113 \dagger$ & 7 & 113 & 1.00 & 0.3 to 2.9 \\
\hline $\begin{array}{l}\text { te Velde ER, van Kooy RJ, Waterreus JJ. Intrauterine insemination of } \\
\text { washed husband's spermatozoa: a controlled study. Fertil Steril } \\
\text { 1989;51:182-5. }\end{array}$ & 13 & 82 & 0 & 61 & 6.72 & 2.1 to 21 \\
\hline $\begin{array}{l}\text { Kirby CA, Flaherty SP, Godfrey BM, Warnes GM, Matthews CD. A } \\
\text { prospective trial of intrauterine insemination of motile spermatozoa } \\
\text { versus timed intercourse. Fertil Steril 1991;56:102-7. }\end{array}$ & 7 & 58 & 4 & 52 & 1.62 & 0.5 to 5.6 \\
\hline $\begin{array}{l}\text { Check JH, Spirito P. Higher pregnancy rates following treatment of } \\
\text { cervical factor with intrauterine insemination without } \\
\text { superovulation versus intercourse: the importance of a well-timed } \\
\text { postcoital test for infertility. Arch Androl 1995;35:71-7. }\end{array}$ & 17 & 80 & 3 & 76 & 4.66 & 1.8 to 11 \\
\hline Common odds ratio & & & & & 2.6 & 1.5 to 4.4 \\
\hline
\end{tabular}

*High intracervical insemination with unprepared semen.

Intrauterine insemination v intracervical insemination (instead of intercourse). 
systematic reviews of its test properties ${ }^{12}$ and our trial have shown. When reviews of test properties concur with a randomised trial, people still need to choose whether evidence, tradition, or opinion should govern their practice. We may well differ from Hull and Evers in our choice.

Cohlen et al seem to advocate intrauterine insemination as a specific treatment for negative postcoital tests, but we do not share their perception of evidence based medicine. When comparing intrauterine insemination with coitus, it does not make sense to tabulate endocervical insemination as equivalent to intrauterine insemination for one trial and equivalent to coitus for another. We also have concerns about the quality of some studies in Cohlen et al's table, and their inclusion and exclusion criteria. In a previous compilation of "five randomised trials," Cohlen et al found an odds ratio of 3.57 instead of the 2.6 reported here, but the studies were not exactly the same as those incorporated here. The reasons for the discrepancy are not apparent, but they are strangely at odds with the accusation that we neglected the guidelines of evidence based medicine by not including all randomised trials.

Cohlen et al may be right that some tests were done more frequently in our control than in our postcoital test group, but frequency of individual tests was not a prior hypothesis. The calculated statistical difference therefore generates rather than answers hypotheses. The request for a compilation of small patient groups, broken down by treatment, by positive or negative test and by achieving pregnancy or not, is even further at odds with evidence based medicine. The answer to a randomised controlled trial that does not confirm one's beliefs is not the conduct of several subanalyses until one can see what one believes. Rather, the answer is to re-examine one's beliefs carefully.

Hendry refers to autoantibodies against spermatozoa as the most common cause of negative postcoital tests. We know of only one study that linked sperm antibodies to postcoital tests; no relation was found. ${ }^{4}$ Others have argued that the link between sperm antibodies and impaired conception is hypothetical. ${ }^{5}$ Our trial found near identical conception rates in women with normal and abnormal postcoital findings.

S Guid Oei Gynaecologist

Department of Obstetrics and Gynaecology, Saint Joseph Hospital, NL-5500 MB, Veldhoven, Netherlands

Frans M Helmerhorst Senior lecturer Department of Obstetrics, Gynaecology and Reproductive Medicine, Leiden, University Medical Center, NL-2300 RC Leiden, Netherlands helmerhorst@mail.medfac.leidenuniv.n

\section{Marc J N C Keirse Professor}

Department of Obstetrics, Gynaecology and Reproductive Medicine, Flinders, University of South Australia, Adelaide, SA 5042, Australia

1 Griffith CS, Grimes DA. The validity of the postcoital test. Am J Obstet Gynecol 1990;162:615-20.

2 Oei SG, Helmerhorst FM, Keirse MJNC. When is the postcoital test normal: a critical appraisal. Hum Reprod 1995;10:1711-4.
3 Cohlen BJ, te Velde ER. Intrauterine inseminatie. In: Evers JLH, Heineman MJ, eds. Fertiliteitsstoornissen. Utrecht Bunge, 1997:125.

4 Ten Brug CS, De Jong-Mulders M, Vermeiden JPW, Bernardus RE, Schoemaker J. Pregnancy rate and incidence of agglutinating antisperm antibodies (AgASA): a retrospective study. Human Reproduction: Abstract of the 10th Annual Meeting of the ESHRE, 1994:97.

5 Taylor PJ, Collins JA. Unexplained infertility. Oxford: Oxford University Press, 1992:128-31.

\section{Value of breast imaging in women with painful breasts}

\section{Negative results are not reassuring}

EDitor-Duijm et al conclude that the primary value of breast imaging in women with painful breasts seems to be that of reassurance, as no abnormalities are usually detected. ${ }^{1}$ Had they measured the level of reassurance that their negative results provided, it seems unlikely they would have come to this conclusion.

There is increasing evidence that negative results of tests at best provide little reassurance and at worst can increase anxiety levels and do considerable harm..$^{2-4} \mathrm{~A}$ recent review concluded that "medical reassurance as currently practised is both ineffective and theoretically contraindicated." ${ }^{55}$ The perpetuation of the myth that patients are reassured by negative results is outdated and potentially dangerous.

Richard D Neal Lecturer in primary care research Centre for Research in Primary Care, Nuffield Institute for Health, University of Leeds, Leeds LS2 9PL

rmrrdn@hyde.leeds.ac.uk

Stephen Morley Professor of clinical psychology Division of Psychiatry and Behavioural Science in Relation to Medicine, University of Leeds

Competing interests: None declared. WPTM. Value of breast imaging in women with painfil breasts: observational follow up study $B M$ 1998;317:1492-5. (28 November)

2 McDonald IG, Daly J, Jelinek VM, Panetta F, Gutman JM. Opening Pandora's box: the unpredictability of reassurance by a normal test result. BMJ 1996;313:329-32.

3 Fitzpatrick R. Telling patients there is nothing wrong. BMJ 1996:313:311-2.

4 Lucock MP, Morley S, White C, Peake MD. Responses of consecutive patients to reassurance after gastroscopy:
cons consecutive patients to reassurance after gastroscopy:
results of self administered questionnaire survey. BMJ

5 Coia P, Morley S. Medical reassurance and patients responses.J Psychosom Res 1998;45:377-86.

\section{Women with severe problems must be seen in specialist breast clinics}

EDITOR-Duijm et al have confirmed that ultrasonography of the breast and mammography are of little diagnostic value in women with breast pain in the absence of clinical signs. ${ }^{1}$ We do not agree, however, with their conclusion that carrying out breast imaging is an appropriate way of reassuring women with breast pain.

Mammography involves ionising radiation and should not be used unless there is a clear clinical indication for it. Duijm et al have shown that for breast pain a clear clinical indication does not exist. Their advice also ignores the possible detrimental effects of false reassurance given by "normal" results of mammography. Mammography has a considerable false negative rate, even in women with palpable breast cancer. ${ }^{2}$

Breast pain is common, particularly in young women, and in most cases can be managed in primary care without referral. Physical examination should be carried out in all cases and is all that is required for the majority of women, who have gone to their doctor for reassurance. The minority, with pain severe enough to require treatment or abnormal clinical signs, should be referred to a specialist breast clinic for diagnosis and advice.

Advice on the best use of imaging, published by the Royal College of Radiologists, specifically states that mammography is not indicated for breast pain. ${ }^{3}$ Furthermore, in the United Kingdom, direct access by general practitioners to breast imaging is not recommended for any symptomatic breast problem. ${ }^{3}{ }^{4}$ Such problems should be seen in breast clinics, where appropriate imaging is carried out only if required after specialist clinical examination.

Guidance on the referral of patients with breast problems was circulated to all general practitioners in 1995 by the UK National Health Service Breast Screening Programme. ${ }^{5}$ This guidance (compiled by a multidisciplinary group) provides concise and practical advice for general practitioners. Advising general practitioners to refer all women with breast pain to a radiologist rather than a surgeon is inappropriate and contrary to guidance on best practice.

Robin Wilson Consultant radiologis

mlzarmw@unix.ccc.nottingham.ac.uk

Roger Blamey Professor of surgical science

Breast Services Directorate, City Hospital,

Nottingham NG12 3RE

1 Duijm LEM, Guit GL, Hendricks JHCL, Zaat JOM, Mal WPTM. Value of breast imaging in women with painful
breasts: observational follow up study. BMJ 1998;317: breasts: observational follo
1492-5. (28 November.)

2 Sibbering DM, Burrell HC, Evans AJ, Yeoman LJ, Wilson ARM, Robertson JFR, et al. Mammographic sensitivity in women under 50 presenting symptomatically with breast cancer. Breast 1995;4:127-9

3 Royal College of Radiologists Working Party. Making the best use of a department of clinical radiology: guidelines for doctors. 4th ed. London: RCR, 1998

4 Breast Surgeons Group of the British Association of Surgical Oncology. Guidelines for surgeons in the management of symptomatic breast disease in the United Kingdom. Eur J Surg Oncol 1995;21(suppl A):3-13.

5 Austoker J, Mansel R, Baum M, Sainsbury R, Hobbs R. Guidelines for referral of patients with breast prob
Sheffield:NHS Breast Screening Programme, 1995 .

\section{More on the Bristol affair}

\section{The affair has had several serious negative outcomes}

EDITOR-Bolsin's audit of the Bristol surgeons' work in 1990-2 was first seen by them in May 1995 after it had been widely reported in the media. It was then found to be flawed. ${ }^{1}$ Bolsin's article also contains several errors, ${ }^{2}$ to some of which I have already responded. ${ }^{13} \mathrm{I}$ was surprised, for example, that he still denied that his audit had been secret, for he had referred to it in those terms at the General Medical Council's inquiry (day 7, 23 October, p 102 of transcript). I note too that he now claims that 
his audit started in $1991^{2}$; when asked at the inquiry whether his data could have been used by Private Eye in April 1992, ${ }^{4}$ he categorically denied starting data collection and analysis before the late summer of that year (see the inquiry's transcripts for day 6 (22 October, pp 81-6) and day 7 (pp 16-20, 24). ${ }^{5}$

It is difficult to understand Bolsin's motivation for continuing to attack the Bristol surgeons after the GMC's harsh determination in June 1998. Until May 1995 he was for seven years a vital member of the surgical team. Anaesthetists share responsibility during cardiac bypass operations for keeping patients alive and their brains well perfused. Has Bolsin ever considered whether he may himself have contributed to the disappointing outcome among 4\% of the surgeons' cases (see day 7 of inquiry's transcripts, $\mathrm{p} 42$ ). ${ }^{5}$

Bolsin has been hailed as a "courageous whistleblower." ${ }^{4}$ But his unilateral approach to the Department of Health in January 1995 had no positive influence on paediatric cardiac surgery in Bristol. The highly effective improvements to the service, first requested by the surgical team in 1989 , had been agreed by the trust several months earlier and were already being implemented. ${ }^{1}$

There were, however, several serious negative outcomes. Bolsin's kind of whistleblowing has been sanctioned and even encouraged. Morale and trust among colleagues have been damaged. The public's confidence in the profession has been undermined. The willingness of doctors to perform high risk interventions to save life, or to undertake honest and open clinical audit, must have been eroded. Critics have been provided with ammunition to attack the profession and hasten changes in regulation, some of which may not be in the best interests of the service. Worst of all, the breach in confidentiality that resulted has led to the opening of emotional wounds among bereaved and grieving parents. These, then, are some of the legacies of this sorry affair to which Bolsin himself has made such an important contribution.

Peter M Dunn Emeritus professor of perinatal medicine and child health

University of Bristol, Southmead Hospital, Bristol BS10 5NB

P.M.Dunn@bristol.ac.uk

1 Dunn PM. The Wisheart affair: reply to Dr Bolsin. $e B M$ 1998;317. (www.bmj.com/cgi/eletters/317/7166/1144\# EL12 [23 December 1998].)

2 Bolsin SN. The Wisheart affair: responses to Dunn. BMJ 1998;317:1579-80. (5 December.)

3 Dunn PM. The Bristol affair. BMJ 1998;317:1659-60. (12 December.)

4 MD. Doing the rounds. Private Eve 1995 May 4:12.

5 MD. Doing the rounds. Private Eye 1995 May 4:12.

\section{Audit was secret yet not confidential}

EDITOR-Guidelines on clinical audit in surgical practice lay down several important points of principle and good practice. ${ }^{1}$ Among the most important is confidentiality, whose rules bind "all members of the clinical team." This confidentiality should apply to data collection, analysis, and the meeting at which the audit is presented. General conclusions should of course be more widely available. The guidelines also state that all members of the clinical team must participate. Thus all parties concerned with the service being audited must know that the audit is being performed. If these basic principles are not respected mutual trust will be lost and the consequences may be disastrous.

The secret audit performed by Bolsin (and on which the General Medical Council's inquiry relied so heavily) fails these fundamental principles. ${ }^{2}$ Prime examples of lack of confidentiality are the articles in Private Eye in May 1992 and $1995 .{ }^{3}{ }^{4}$ The first contained confidential audit data and the second claimed that Bolsin's secret audit "was first published in the Eye." ${ }^{4}$ These data, whatever their state of reliability or completeness, were passed to others outside the team and outside Bristol, but they were not discussed with the paediatric surgeons or cardiologists, who knew nothing of the data collection until 1995.

Clinical audit must be carried out properly, and the data must be accurate and analysed appropriately. Dunn has already commented on the more than fivefold error in death rates in Bolsin's data for ventricular septal defect operations. ${ }^{5}$ Although Bolsin privately acknowledged the error in 1995 , this did not become public until the GMC's inquiry in 1997. Since the inaccurate data had previously been leaked to the media, a recognised error was allowed to persist uncorrected in the public perception for at least two years. This emphasises the danger of inaccurate data collection with lack of confidentiality.

The guidelines also state that "audit meetings should be followed by action, when indicated, to improve clinical results." Bolsin's audit (not shown to the surgeons or chief executive until 1995) did not even achieve this objective. The organisational and structural changes, first proposed by the much maligned paediatric cardiac surgeons and their cardiologist colleagues in 1989 had already been set in train by mid- 1994 .

So what lessons can we learn? Among the most important is that audit must be governed by principles of good practice. Without them, results cannot be relied on and mutual trust is wantonly destroyed not only between healthcare professionals but also among the public.

Gordon M Stirrat Professor of obstetrics and gynaecology

University of Bristol, St Michael's Hospital, Bristol BS2 8EG

g.m.stirrat@bristol.ac.uk

1 Royal College of Surgeons of England. Clinical audit in surgical practice. 1st ed. London: RCS, 1989. (Revised June 1995.)

2 Bolsin S. The Wisheart affair: responses to Dunn. BM 1998;317:1579-80. (5 December.)

3 MD. Doing the rounds. Private Eye 1992 May 8:13.

4 MD. Doing the rounds. Private Eye 1995 May 4:12.

5 Dunn PM. The Wisheart affair: reply to Dr Bolsin. $e B M$

1998:317. (www.bmj.com/cgi/eletters/317/7166/1144\#

EL12 [23 December 1998] ?

\section{Audit was not secret}

EDITOR-In his letter on the BMJ's website Stirrat emphasises several points from the original document on clinical audit in surgical practice. ${ }^{12}$ As the first national audit coordinator for the Association of Cardiothoracic Surgeons of Great Britain and Ireland I was well aware of the ground rules governing audit in clinical practice. He did not say that all of these points are qualified by the phrase "under normal circumstances." What was occurring in Bristol's paediatric cardiac surgery unit was not normal (in fact it was judged by the General Medical Council to have been serious professional misconduct), and consequently normal considerations did not apply. ${ }^{3}$

Stirrat should also know that the secret audit he refers to was authorised in 1992 by Professor Cedric Prys-Roberts, head of the university department of anaesthetics at the Bristol Royal Infirmary, and the results were shown to him on completion in early 1993. Professor Prys-Roberts immediately discussed the results with Dr John Roylance, then chief executive of the United Bristol Healthcare Trust (which included the Bristol Royal Infirmary). The results were also shown to Professor Gianni Angelini, head of the university department of cardiac surgery at the infirmary, Dr Chris Monk, director of anaesthesia at the infirmary (and a paediatric cardiac anaesthetist), Dr Sally Masey, senior paediatric cardiac anaesthetist at the infirmary, and Professor John Vann-Jones when he was the clinical director of cardiac services, which included paediatric cardiac surgery. ${ }^{4}$ To describe a survey that was circulated as widely as this at very high levels in the Bristol Royal Infirmary as secret shows a staggering but understandable ignorance on the part of Stirrat, who, of course, did not work at the infirmary. Both Professors Stirrat and Dunn were close friends of $\mathrm{Mr}$ Wisheart, and they may have allowed this to colour their appreciation of events. The editors of scientific journals may need to bear this in mind when considering publishing future material from these sources. ${ }^{5}$

I do not deny that the paediatric cardiac surgeons and cardiologists proposed structural changes to the service in 1989 and that they were implemented later. My concern was that the high mortality for some surgeons for several procedures exposed children to the risk of excess mortality from these operations at the Bristol Royal Infirmary after changes were proposed for whatever reason. I would like to think that I can take a small amount of the credit for some of the action that has resulted in the improvement in overall death rates in the new service at the Royal Bristol Children's Hospital compared with the service that existed in 1995 at the Bristol Royal Infirmary.

Stephen Bolsin Director of perioperative medicine, anaesthesia and pain management Geelong Hospital, Victoria 3220, Australia STEVEB@BarwonHealth.org.au 
1 Stirrat GM. The Bristol affair: Audit-secret yet not confidential. eBMJ 1998;317. (www.bmj.com/cgi/eletters/ 7172/1579 [31 December].)

2 Royal College of Surgeons of England. Clinical audit in surgical practice. 1st ed. London: RCS, 1989.

3 Dyer C. Bristol doctors found guilty of serious professional misconduct. BMJ 1998;316:1924. (27 June.)

Bolsin SN. Professional misconduct: the Bristol case. Med J Aust 1998;169:369-72.

5 Dunn PM. The Wisheart affair: paediatric cardiological services in Bristol 1990-5. BMJ 1998;317:114-5. (24 October.)

\section{What went wrong and how can we move forward?}

EDITOR-Doctors can make mistakes - this is not the issue. The issue is how mistakes are dealt with. A problem addressed can be rectified-a problem concealed cannot. Our concern is that resistance to acknowledging problems in Bristol Royal Infirmary's cardiac unit blocked improvement. As early as 1983 the unit was seen as unsafe, and in 1989 it was identified as substandard.

How did Mr Wisheart, who was both medical director of the United Bristol Healthcare Trust and chairman of the hospital medical committee (both defendant and judge), react to these findings?

Even if a senior cardiac surgeon ignored his own unit's failings, was there no one in higher authority to bring them to his attention? In July 1992 the Royal College of Surgeons made its concerns known to the Department of Health-to no avail. In January 1995 not even a telephone call from the Department of Health could halt a nonemergency - and fatal-operation.

Bristol was an avoidable tragedy and is not unique. Because of its limited remit the General Medical Council took us no nearer to finding out why the entire system failed. Neither does the GMC have powers to bring charges against doctors' competence. In other words, doctors have clinical freedom without clinical accountability.

What is the way forward? One way is through clinical audit. Although the Royal College of Surgeons is promoting league tables for coronary bypass grafting, we suggest that this audit system is open to abuse. For an effective model we need to look at present day Bristol for a transparent and accountable process.

Bristol's cardiac data are published on a website (www.bht.org.uk). Collected prospectively, they cover a range of operations (not only coronary artery bypass grafting) and give a clear picture of the surgeons' competence. Surprisingly, this model operates in only five out of 40 cardiac centres although it is not expensive to implement.

We know mistakes happen in spite of doctors trying hard. What we seek is an audit system which identifies problems early. Until audit is driven by patient benefit, not professional loyalties, mistakes will continue to be concealed.

Maria Shortis Mother of child who had cardiac surgery in Bristol

Elisabeth Winkler Mother of child who had cardiac surgery in Bristol

Constructive Dialogue for Clinical Accountability, 54 Alma Vale Road, Bristol BS8 2HS

101636.1720@compuserve.com

One child died in 1987 and the other, who was operated on in July 1998, recovered fully.

\section{Look at this case again}

EDITOR-Charlotte was born on the 12 March 1987 with multiple congenital heart defects. After the diagnosis was made she was placed into the care of Mr Wisheart. He did not have the arrogance you sometimes find in men of his standing, but he instead displayed dedication, gentleness, and honesty. My husband and I found him to be generous with his time, and he always ensured that Charlotte received the best possible care.

Mr Wisheart was particularly meticulous in planning the operations. Every consideration was taken into account. It was important that it was the best choice for the child. We were informed every step of the way; never were we misled or misinformed. The possibility of brain damage was mentioned, as were possible problems when removing children from the ventilator. There was also the uncertainty that until the heart is viewed directly the surgeon cannot be sure that the tests have shown every abnormality. We were aware of all these possibilities and more. The parents were also kept informed by the cardiologists and supported by the cardiac liaison officer.

In Bristol in 1988 open heart surgery for children was carried out at the Royal Infirmary. Diagnosis and closed surgery was done at Bristol's Children's Hospital. Charlotte's operation was carried out in June 1988, and her recovery was long and difficult. She died in March 1989.

The General Medical Council's findings showed these children did not die because of any lack of surgical skill. Many were desperately ill; it was our responsibility as parents not to rob our children of a second chance of life. It's because of people like $\mathrm{Mr}$ Wisheart who have devoted their lives to such matters that these chances are possible at all.

My husband, also born with multiple heart defects, was operated on by $\mathrm{Mr}$ Wisheart, when success rates were much lower. Robert is fit and healthy and looks forward to a long life with our children, Lucy and Christian. In all those years $\mathrm{Mr}$ Wisheart's dedication to those in his care has been constant, making himself totally accessible to staff, parent, and patient alike. We can argue $\mathrm{Mr}$ Wisheart's case because during the 20 years we have known him we've been privileged to see how he thinks, what he believes, and how he works.

Please look at this case again and look at it through open eyes.

Michelle Cummings Mother of child who was operated on by $\mathrm{Mr}$ Wisheart

61 New Cheltenham Road, Kingswood, South Gloucester BS15 1UL

\section{Use of asthma drugs is less among women pregnant with boys rather than girls}

EDITOR-Beecroft et al reported an intriguing association between the sex of the fetus and symptoms of asthma during pregnancy. ${ }^{1}$ They speculated that women preg-
Sex of fetus and use of asthma drugs among asthmatic women during pregnancy. Values are numbers of women (percentages of male or female fetuses)

\begin{tabular}{lccc} 
Sex of fetus & $\begin{array}{c}\text { No drug } \\
\text { treatment } \\
(\mathbf{n}=\mathbf{3 7 5})\end{array}$ & $\begin{array}{c}\boldsymbol{\beta} \text { agonist } \\
\text { alone }(\mathbf{n = 3 0 3 )}\end{array}$ & $\begin{array}{c}\text { Steroids } \\
(\mathbf{n}=\mathbf{1 3 9})\end{array}$ \\
\hline Male $(\mathrm{n}=415)$ & $192(46)$ & $164(40)$ & $59(14)$ \\
\hline Female & $183(46)$ & $139(35)$ & $80(20)$
\end{tabular}

nant with boys have improved asthma symptoms during pregnancy, possibly because of androgen production by male fetuses. We recently reported a population based study from Nova Scotia, Canada, of perinatal outcomes in women with asthma during pregnancy, but we did not consider fetal sex. ${ }^{2}$

Although we do not have specific data on asthma severity or symptoms, pregnant asthmatic women were divided into three treatment groups: no use of drugs during pregnancy, $\beta$ agonists alone, and steroids with or without other asthma drugs. The table shows that $14 \%$ of women pregnant with a boy required steroids during pregnancy compared with $20 \%$ of women pregnant with a girl. Conversely, more women pregnant with a girl used $\beta$ agonists alone than did women pregnant with a boy.

If asthmatic patients requiring steroids are assumed to have more severe symptoms than those not taking steroids or those taking $\beta$ agonists alone, our data support the association noted by Beecroft et al. Unfortunately, we cannot confirm this assumption and conclude that this interesting association is worthy of further study.

L Dodds Epidemiologist

Reproductive Care Programme, 5980 University Avenue, Halifax, Nova Scotia, Canada

B3H $4 \mathrm{~N} 1$

dodds@is.dal.ca

B A Armson Obstetrician

Department of Obstetrics and Gynaecology, Dalhousie University, Halifax, Nova Scotia, Canada B3H 4N1

S Alexander Epidemiologist

Newfoundland and Labrador Provincial Perinatal Programme, St John's, Newfoundland, Canada A1A 1 R8

1 Beecroft N, Cochrane GM, Milburn HJ. Effect of sex of fetus on asthma during pregnancy: blind prospective study. BMJ 1998;317:856-7. (26 September.)

2 Alexander S, Dodds L, Armson BA. Perinatal outcomes in women with asthma during pregnancy. Obstet Gynecol 1998;92:435-40.

\section{Australian university students agree with Clinton's definition of sex}

EDitoR-Since 1988 we have surveyed first year students in behavioural sciences at Macquarie University in Sydney on their attitudes to and knowledge of HIV and AIDS and relevant risk behaviours. In 1998 we asked 545 students aged 17 to 73 (median age $19 ; 62 \%$ under 20 ) which of the 
following activities count as "having sex with" someone: tongue kissing, touching or stroking sexual organs with the hand (mutual masturbation), oral sex (mouth on penis or vulva) with or without orgasm, and penetration of the vagina or anus by a penis with or without ejaculation.

Only 7\% (33/471) regarded tongue kissing as having sex, 30\% (140/470) regarded touching or stroking, $54 \% \quad(258 / 476)$ regarded oral sex without orgasm, and 58\% $(275 / 475)$ regarded oral sex with orgasm as having sex. Over 99\% (491/494) agreed that penis-vagina sex with ejaculation was sex, and $97 \%(477 / 492)$ thought it was even if no ejaculation occurred. About 10\% excluded anal sex from their definition of sex.

Older students were far more likely to rate non-intercourse activities as sex: $3 \%$ $(10 / 311)$ of those under 20 and $14 \%$ $(22 / 156)$ of those over 20 counted tongue kissing as sex; $49 \%(152 / 309)$ of those under 20 and $74 \%(120 / 162)$ of those over 20 counted oral sex with orgasm. All of the 21 students over age 40 thought that oral sex with orgasm was sex. Men were somewhat more likely than women to count non-coital sex as having sex.

The 5\% $(30 / 551)$ of respondents who were not heterosexual (that is, those who identified themselves as gay, lesbian, or bisexual, or did not answer the question) regarded more activities as sex, but the differences were not statistically significant. The exception was touching and stroking, which $50 \%(12 / 24)$ of non-heterosexuals but only $29 \%(128 / 446)$ of heterosexuals regarded as sex.

These results are likely to be representative of Australian students in general. The sexual knowledge, attitudes, and behaviours of these university students have been shown to be little different from those of randomly selected students studying other subjects at other universities. ${ }^{1}$ Questionnaires were handed out by us, not by the teachers, in a large lecture theatre and completed anonymously. Very few $(<1 \%)$ students refused the survey altogether; nonresponse for questions varied between 10\% and $15 \%$.

Researchers should clarify their definitions if they want younger respondents to include non-coital sex in their reports of sexual activities and partners. It is possible that HIV prevention campaigns which emphasised the use of condoms over the past decade may have fostered the view that the only real sex is the sort you use a condom for. This will make it more difficult to promote non-coital sex as safe sex.

Juliet Richters Research fellow

Angela Song Research officer

National Centre in HIV Social Research, University of New South Wales, Sydney, NSW 2052, Australia

1 Van de Ven P, Turtle A, Kippax S, Crawford J, French J. Trends in heterosexual tertiary students' knowledge of HIV and intentions to avoid people who might have HIV. AIDS Care 1996; 8:43-53.

\section{Prevalence of smoking among pregnant women is lower in Italy than England}

EDITOR-Owen et al report that the prevalence of smoking in pregnancy and the rates of stopping did not change in England between 1992 and 1995, remaining at around 25\%. ${ }^{1}$ They also reported that the prevalence of smoking in pregnancy is higher in young women, unemployed women, and manual workers.

We analysed the characteristics of women who gave up or continued smoking during pregnancy in Italy, using the comvarious obstetric conditions conducted in Italy between 1990 and $1995 .^{2}$ A total of 1542 women aged 14-41 (median age 30) who delivered healthy infants at term $(>37$ weeks' gestation) on selected days in several hospitals, including those with the largest obstetric departments in greater Milan, were included in our analysis. Data were collected by trained interviewers using a structured questionnaire. Reliability ${ }^{3}$ and validity (based on saliva cotinine analysis ${ }^{4}$ ) of self reported smoking in pregnancy were satisfactory.

Altogether $1122(72.8 \%)$ women were never smokers at conception, $232(15.0 \%)$ stopped during pregnancy (195 (84\%) of them during the first trimester), and 188 $(12.2 \%)$ smoked during pregnancy.

The table gives the prevalence of smoking in pregnancy according to age and selected variables. The prevalence was lower in women aged $<25$ than in those aged quitting declined with age to 0.4 (95\% confidence interval 0.2 to 0.8 ) for women aged $\geqslant 35$ versus those aged $<25$. Never married women were more frequently smokers in parison group of a case-control study of $\geqslant 35(11.4 \%$ v $13.5 \%)$; the odds ratios of

pregnancy than married women $(20.8 \% v$ $11.9 \%$ ). More educated women were less frequently smokers than less educated women $(10.0 \% v 28.6 \%)$ and had an odds ratio of quitting of 2.4 (1.0 to 5.2). Women with two or more previous births were more frequently smokers $(17.8 \% v 11.4 \%)$ and less frequently quit (odds ratio 0.2 (0.1 to 0.5$)$ ).

These data show a lower reported prevalence of smoking among pregnant women in Italy than in England. This reflects a lower overall prevalence of smoking among Italian women $\left(17 \%\right.$ in $\left.1995^{5}\right)$. Our data confirm the finding of Owen et al that smoking in pregnancy is more common among never married, less educated women; priority interventions should therefore be targeted at these groups.

Liliane Chatenoud Senior scientis Francesca Chiaffarino Research fellow

Fabio Parazzini Head, unit of analytical epidemiology Istituto di Ricerche Farmacologiche "Mario Negri," 20157 Milan, Italy

Guido Benzi Researcher

Prima Clinica Ostetrico Ginecologica, Università di Milano, Milan

Carlo La Vecchia Associate professor of epidemiology Istituto di Statistica Medica e Biometria, Università di Milano, 20133 Milan

1 Owen L, McNeill A, Callum C. Trends in smoking during pregnancy in England, 1992-7: quota sampling surveys. BMJ 1998;317:728. (12 September.)

2 Chatenoud L, Parazzini F, Di Cintio E, Zanconato G, Benzi G, Bortolus R, et al. Paternal and maternal smoking habits before conception and during the first trimester: relation to spontaneous and dung the first trimester: rela

3 D'Avanzo B, La Vecchia C, Katsouyanni K, Negri E, D'Avanzo B, La Vecchia C, Katsouyanni K, Negri E,
Trichopoulos D. Reliability of information on cigarette Trichopoulos D. Reliability of information on cigarette
smoking and beverage consumption provided by hospital smoking and beverage consumption
controls. Epidemiology 1996;7:312-5.

controls. Epidemiology 1996;7:312-5.
4 Parazzini F, Davoli E, Rabaiotti M, Restelli S, Stramare L, Parazzini F, Davoli E, Rabaiotti M, Restelli S, Stramare L,
Dindelli M, et al. Validity of self-reported smoking habits in pregnancy: a saliva cotinine analysis. Acta Obstet Gynecol Scand 1996;75:352-4.

5 Pagano R, La Vecchia C, Decarli A. Smoking in Italy, 1995. Tumori 1998;84:456-9.

Prevalence of smoking during pregnancy according to age and selected variables, Italy, 1990-5. Figures are numbers (percentages)

\begin{tabular}{|c|c|c|c|c|c|}
\hline & $\begin{array}{c}\text { No of } \\
\text { subjects }\end{array}$ & Non-smokers & $\begin{array}{l}\text { Quit during } \\
\text { pregnancy }\end{array}$ & $\begin{array}{l}\text { Smoked during } \\
\text { pregnancy }\end{array}$ & $\begin{array}{l}\text { Odds ratio of quitting } \\
\text { smoking }(95 \% \mathrm{Cl})^{*}\end{array}$ \\
\hline \multicolumn{6}{|l|}{ Age (years): } \\
\hline$<25$ & 184 & $118(64.1)$ & $45(24.5)$ & $21(11.4)$ & $1 \dagger$ \\
\hline $25-29$ & 452 & $329(72.8)$ & $73(16.2)$ & $50(11.1)$ & $0.7(0.4$ to 1.3$)$ \\
\hline $30-34$ & 609 & $453(74.4)$ & $79(13.0)$ & 77 (12.6) & $0.5(0.3$ to 0.9$)$ \\
\hline$\geqslant 35$ & 297 & $222(74.8)$ & $35(11.8)$ & 40 (13.5) & $0.4(0.2$ to 0.8$)$ \\
\hline \multicolumn{6}{|l|}{ Marital status: } \\
\hline Ever married & 1489 & $1089(73.1)$ & $223(15.0)$ & $177(11.9)$ & $1 \dagger$ \\
\hline Never married & 53 & $33(62.3)$ & $9(17.0)$ & $11(20.8)$ & $0.6(0.2$ to 1.5$)$ \\
\hline \multicolumn{6}{|l|}{ Education (years): } \\
\hline$<6$ & 63 & $33(52.4)$ & $12(19.1)$ & $18(28.6)$ & $1 \dagger$ \\
\hline $6-12$ & 546 & $380(69.6)$ & $89(16.3)$ & $77(14.1)$ & $1.6(0.7$ to 3.6$)$ \\
\hline$\geqslant 13$ & 933 & $709(76.0)$ & $131(14.0)$ & $93(10.0)$ & 2.4 (1.0 to 5.2$)$ \\
\hline$\chi_{1}^{2}$ for trend & & & & & 6.72 \\
\hline \multicolumn{6}{|c|}{ No of previous births: } \\
\hline 0 & 867 & $608(70.1)$ & $160(18.5)$ & $99(11.4)$ & $1 \dagger$ \\
\hline 1 & 540 & $410(75.9)$ & $65(12.0)$ & $65(12.0)$ & $0.7(0.4$ to 1.1$)$ \\
\hline$\geqslant 2$ & 135 & $104(77.0)$ & $7(5.2)$ & $24(17.8)$ & $0.2(0.1$ to 0.5$)$ \\
\hline$\chi_{1}^{2}$ for trend & & & & & 11.44 \\
\hline \multicolumn{6}{|c|}{ Drank alcohol during pregnancy: } \\
\hline No & 1019 & $741(72.7)$ & $156(15.3)$ & $122(12.0)$ & $1 \dagger$ \\
\hline Yes & 523 & $381(72.9)$ & $76(14.5)$ & $66(12.6)$ & $1.0(0.7$ to 1.5$)$ \\
\hline Total in study & 1542 & $1122(72.8)$ & $232(15.0)$ & $188(12.2)$ & - \\
\hline
\end{tabular}

${ }^{*}$ Adjusted for age in five year bands. †Reference category. 
The profession, not the media, should assess where Kasai portoenterostomy should be performed

EDIToR-The Children's Liver Disease Foundation recently published its report into the treatment of infants with biliary atresia by Kasai portoenterostomy. ${ }^{1}$ This was covered in the BBC's news programme Northwest Tonight and in Trust Me, I'm a Doctor on 26 February. The report advocates that Kasai portoenterostomy should be performed only in centres that can produce outcome figures equivalent to those produced by group $\mathrm{C}$ in the table. Furthermore, the relevant professional bodies should encourage all surgeons to refer patients to such centres. Finally, it emphasises that all surgeons should fully inform parents about experience and outcome in their centre and the outcome of centres operating on more than five infants a year.

The foundation funded a survey by the British Paediatric Surveillance Unit of cases of extrahepatic biliary atresia occurring between 1993 and 1995. The preliminary data from this study (table), together with a previous study, ${ }^{2}$ formed the basis of their recommendations. Median follow up was 3 years, with a successful Kasai procedure being determined by clearance of jaundice.

Unfortunately, the media representation of these data in the television programmes and elsewhere ${ }^{3}{ }^{4}$ has been inaccurate and misleading. Although importantly emphasising the differences between groups $\mathrm{A}$ and $\mathrm{C}$ and publicising the success of hospitals in group $\mathrm{C}$, the acknowledgment of comparable success in the centres of group B was conspicuously absent.

\section{Advice to authors}

We prefer to receive all responses electronically, sent either directly to our website or to the editorial office as email or on a disk. Processing your letter will be delayed unless it arrives in an electronic form.

We are now posting all direct submissions to our website within 72 hours of receipt and our intention is to post all other electronic submissions there as well. All responses will be eligible for publication in the paper journal.

Responses should be under 400 words and relate to articles published in the preceding month. They should include $\leqslant 5$ references, in the Vancouver style, including one to the BMJ article to which they relate. We welcome illustrations.

Please supply each author's current appointment and full address, and a phone or fax number or email address for the corresponding author. We ask authors to declare any competing interest. Please send a stamped addressed envelope if you would like to know whether your letter has been accepted or rejected.

Letters will be edited and may be shortened.

www.bmj.com

letters@bmj.com
Outcome of Kasai portoenterostomy for extrahepatic biliary atresia, 1993-5

\begin{tabular}{lcccc}
$\begin{array}{l}\text { No of cases } \\
\text { per year }\end{array}$ & $\begin{array}{c}\text { No of } \\
\text { surgical } \\
\text { centres }\end{array}$ & $\begin{array}{c}\text { Total No } \\
\text { of } \\
\text { patients }\end{array}$ & $\begin{array}{c}\text { Median } \\
\text { age at } \\
\text { surgery } \\
\text { (days) }\end{array}$ & $\begin{array}{c}\text { No (\%) of } \\
\text { successful } \\
\text { Kasai } \\
\text { procedures }\end{array}$ \\
\hline 1 (group A) & 8 & 12 & 56 & $2(17)$ \\
\hline $2-5$ (group B) & 5 & 24 & 53 & $13(54)$ \\
\hline$>5$ (group C) & 2 & 55 & 53 & $35(64)$ \\
\hline
\end{tabular}

Regional centres for paediatric gastroenterology should be encouraged to continue providing a service to the local community when they have experience in diagnosing and managing liver disease in children, satisfactory success rates for Kasai portoenterostomy, and established links with a supraregional or transplant centre for timely referral. Unnecessary centralisation will compromise affected families both socially and economically and undermine their confidence in well established units that have served their population effectively over decades.

We support the Children's Liver Disease Foundation in requesting further evaluation of the provision of Kasai portoenterostomy. This evaluation should assess the service provided by all centres wishing to continue providing Kasai portoenterostomy and should be performed by the relevant professional bodies and not the media.

S Davison Consultant in paediatric gastroenterology V Miller Consultant in paediatric gastroenterology A Thomas Consultant in paediatric gastroenterology

$\mathrm{J}$ Bowen Consultant in paediatric surgery

J Bruce Consultant in paediatric surgery

Departments of Paediatric Gastroenterology and Paediatric Surgery, Booth Hall Children's Hospital and Royal Manchester Children's Hospital, Manchester Children's Hospital NHS Trust, Manchester M27 1HA

1 Children's Liver Disease Foundation. Report into the treatment of infants with biliary atresia by Kasaiportoenterostomy Birmingham: Children's Liver Disease Foundation, 1999. (Available from Children's Liver Disease Foundation, 35-37 Great Charles Street, Queensway, Birmingham B3 3JY.)

2 McClement JW, Howard ER, Mowat AP. Results of surgical 2 McClement JW, Howard ER, Mowat AP. Results of surgical treatment for extrahepatic biliary a
Kingdom, 1980-2. BMJ 1985:290:345-7.

Kingdom, 1980-2. BMJ 1985;290:345-7.
MD. Doing the rounds. Private Eye 1998 Aug 21:12

4 MD. Doing the rounds. Private Eye 1998 Aug 21:12

\section{Political correctness is behind proposed appraisal system}

Editor-The Royal College of Physicians may be suffering from a bout of political correctness, or it could be more serious, indicating early signs of a complete loss of touch with reality. ${ }^{1}$ Apparently, the London "branch" of the Royal College of Physicians feels the need to introduce annual appraisals for all consultant physicians. These will be undertaken by medical or clinical directors within each trust and are a consequence of the public expecting higher standards and less variability in practice.

Although appraisals may have a laudable aim, some questions need to be addressed:
- What is the evidence that physicians are currently failing to achieve appropriate standards?

- The appointments of many clinical and medical directors are based on management criteria and thus may have a political dimension. This could have implications for the results of a particular appraisal. Who is going to appraise the appraisers?

- Appraisals may be politically correct and very $90 \mathrm{~s}$, but is there any evidence that they make a difference to the care of patients? If problems are recognised to be a

consequence of a lack of funding will the individual trust have the financial capability to deal with this?

- Is there money to pay for additional further postgraduate education, and who is going to deal with the inevitable increase in waiting times for outpatients?

The fundamental issue will be the method of assessment: will this involve multiple choice questions on academic minutiae of little relevance to clinical practice or will it depend on patients' views of their doctor's competence? Perhaps it would be simpler to ask patients whether $\operatorname{Dr} \mathrm{X}$ is doing a good job. Then Dr X could ask whether they have been good patients ... sorry, is that politically incorrect?

David Kerr Consultant physician

The Gables, 71 Bure Lane, Christchurch, Dorset BH23 4DL

david.kerr@rbch-tr.swest.nhs.uk

1 Beecham L. Consultant physicians should be appraised annually. BMJ 1999;318:419. (13 February.)

\section{Prescribing antibiotics for sore throats}

\section{Doctor uses different method from} authors

EDITOR-Butler et al did not report a procedure that I use when faced with either a sore throat about which I am unsure or patients asking for antibiotics for their sore throat. ${ }^{1} \mathrm{I}$ tell such patients that I think the cause of their sore throat is viral but that I will take a throat swab, with the promise that if their throat is still sore when the swab result is known I will prescribe an antibiotic on the basis of that result. Most seem happy-at least I don't see many of these patients again.

Andrew Sanderson General practitioner

Adan House, Spennymoor, County Durham DL16 6QA

1 Butler CC, Rollnick S, Pill R, Maggs-Rapport F, Stott N. Understanding the culture of prescribing: qualitative study of general practitioners' and patients' perceptions of study of general practitioners' and patients' perceptions of
antibiotics for sore throats. BMJ 1998;317:637-42. (5 September.)

Rapid responses
$\begin{aligned} & \text { Rapid responses submitted directly to our } \\ & \text { website are available on www.bmj.com }\end{aligned}$

